\title{
Silicon Nitride Film by Inline PECVD for Black Silicon Solar Cells
}

\author{
Bangwu Liu, Sihua Zhong, Jinhu Liu, Yang Xia, and Chaobo Li \\ Key Laboratory of Microelectronics Devices \& Integrated Technology, Institute of Microelectronics, Chinese Academy of Sciences, \\ Beijing 100029, China
}

Correspondence should be addressed to Bangwu Liu, liubangwu@ime.ac.cn

Received 9 May 2012; Revised 13 July 2012; Accepted 15 July 2012

Academic Editor: F. Yakuphanoglu

Copyright (c) 2012 Bangwu Liu et al. This is an open access article distributed under the Creative Commons Attribution License, which permits unrestricted use, distribution, and reproduction in any medium, provided the original work is properly cited.

The passivation process is of significant importance to produce high-efficiency black silicon solar cell due to its unique microstructure. The black silicon has been produced by plasma immersion ion implantation (PIII) process. And the Silicon nitride films were deposited by inline plasma-enhanced chemical vapor deposition (PECVD) to be used as the passivation layer for black silicon solar cell. The microstructure and physical properties of silicon nitride films were characterized by scanning electron microscope (SEM), Fourier transform infrared spectroscopy (FTIR), spectroscopic ellipsometry, and the microwave photoconductance decay ( $\mu$-PCD) method. With optimizing the PECVD parameters, the conversion efficiency of black silicon solar cell can reach as high as $16.25 \%$.

\section{Introduction}

Black silicon is an effective method to reduce the surface reflectivity for optoelectronic devices and solar cells application. Many black silicon methods have been developed, including reactive ion etching [1], metal-assisted chemical etching [2], and irradiating the silicon surface with femtosecond laser pulses [3]. In our previous study [4, 5], plasma immersion ion implantation (PIII) process has been put forward to produce black silicon with advantages of low cost and high throughput. During the PIII process, the reactive ions are injected into the silicon lattice and react with silicon, and then black silicon with various microstructures can be formed. Although the black silicon has very low surface reflectivity, the conversion efficiency can not be improved significantly when the black silicon is used for solar cells application. In order to produce high-efficiency black silicon solar cell, the matching process (e.g., Phosphorus diffusion process, PECVD $\mathrm{SiN}_{x}$ film process, and cofiring process) should be improved. Due to the unique microstructure of the black silicon, the passivation process is of significant importance to produce high-efficiency solar cell. PECVD $\mathrm{SiN}_{x}$ film is widely used in photovoltaic industry, which cannot only be used as antireflective coating (ARC) but also provide surface passivation effect and excellent bulk passivation for multicrystalline silicon solar cell due to a large amount of hydrogen originating from plasma gas dissociation and incorporated in the $\mathrm{SiN}_{x}$ film [6].

In the present study, PECVD $\mathrm{SiN}_{x}$ film is used to passivate the black silicon for solar cells. A detailed study on the physical properties of the as-grown $\mathrm{SiN}_{x}$ films as functions of the PECVD parameters will be carried out. The passivation effects of the $\mathrm{SiN}_{x}$ film on the black silicon solar cell will also be discussed.

\section{Experimental Details}

The material used for experiments was commercially available boron-doped p-type multicrystalline silicon wafers obtained from the ingot by wire sawing of thickness $\sim 200 \mu \mathrm{m}$, area $156 \mathrm{~mm} \times 156 \mathrm{~mm}$, and resistivity $1 \sim 3 \Omega \mathrm{cm}$. Damage on the surface induced by wire cutting was removed by etching in $10 \% \mathrm{NaOH}$ solution at $80^{\circ} \mathrm{C}$. The black silicon was prepared by plasma immersion ion implantation process on home-made equipment and subsequently subjected to acid etching in $2 \% \mathrm{HCl}$ and then in $10 \% \mathrm{HF}$ to remove the contamination and oxides. After that, the black silicon wafers were phosphorus doped using phosphorous oxychloride $\left(\mathrm{POCl}_{3}\right)$ as the dopant source and then subjected to edge etching through reactive ion etching and removing 


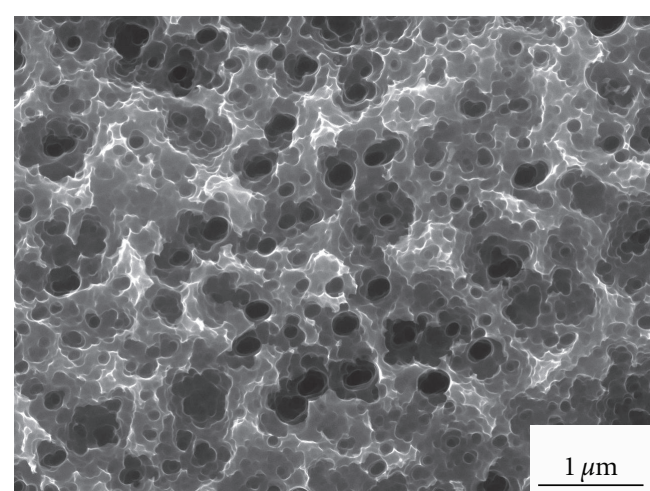

(a)

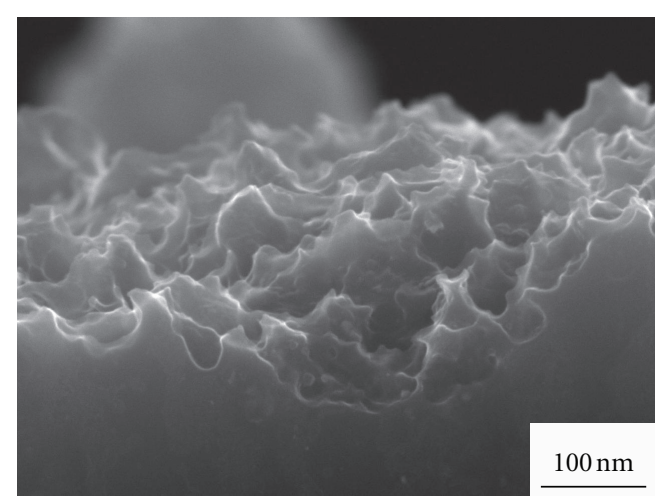

(b)

FIgUre 1: The microstructure of the black silicon produced by PIII (a) top view and (b) cross-sectional view of the black silicon.

phosphosilicate glass (PSG) layer with diluted HF (10\% by volume). Silicon nitride film for passivation was grown by PECVD process with different gas flow ratios of $\mathrm{NH}_{3} / \mathrm{SiH}_{4}$, deposition time and deposition temperatures. Finally, the front and back metallization of all the black silicon wafers was carried out by screen-printing technique and followed by baking and cofiring in a conveyer belt furnace.

The structure and physical properties of silicon nitride were characterized by scanning electron microscope (SEM), Fourier transform infrared spectroscopy (FTIR), spectroscopic ellipsometry, and the microwave photoconductance decay $(\mu$-PCD) method. The surface reflectance was examined by a UV-VIS-NIR spectrophotometer (Varian Cary 5000) equipped with an integrating sphere detector in the wavelength from 300 to $1100 \mathrm{~nm}$. $I-V$ characterization was used to evaluate the black silicon solar cell under one sun global solar spectrum of AM 1.5 at $25^{\circ} \mathrm{C}$.

\section{Results and Discussion}

3.1. The Microstructure of Black Silicon. The microstructure of the black silicon produced by PIII is shown in Figure 1 . The surface of the black silicon appears to be porous sponge like microstructure. The evaluated dimension of randomly distributed structures is less than $1 \mu \mathrm{m}$ (varied from $100 \mathrm{~nm}$ to $300 \mathrm{~nm}$ ). Due to such morphology, a reduced effective

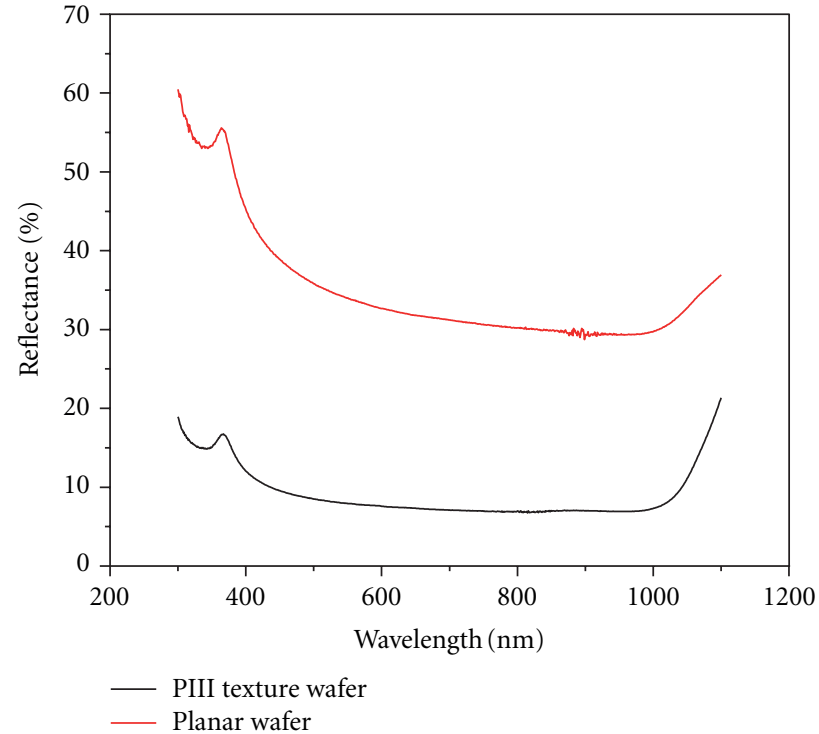

FIgURE 2: The reflectance of the PIII textured wafer and planar wafer varying with wavelength from $300 \mathrm{~nm}$ to $1100 \mathrm{~nm}$.

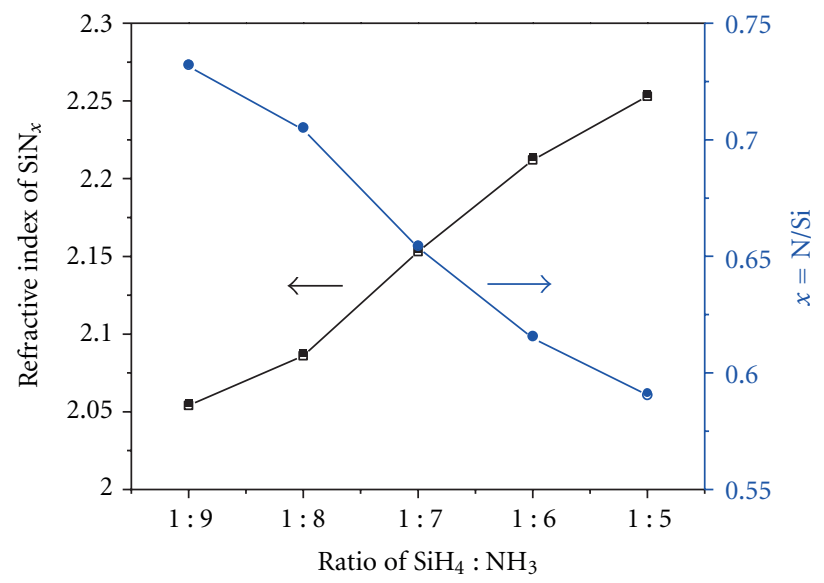

FIGURE 3: The refractive index and stoichiometry of $\operatorname{SiN}_{x}$ varying with the ratio of $\mathrm{SiH}_{4}: \mathrm{NH}_{3}$.

reflectance value about 7\% in the wavelength from $300 \mathrm{~nm}$ $1100 \mathrm{~nm}$ is obtained, presented in Figure 2.

3.2. Gas Flow Ratio. The $\mathrm{NH}_{3} / \mathrm{SiH}_{4}$ gas flow ratio is the most important factor affecting the properties of the silicon nitride $\left(\mathrm{SiN}_{x}\right)$ film. Keeping other parameters (deposition temperature, deposition time, plasma power, etc.) constant, the $\mathrm{NH}_{3} / \mathrm{SiH}_{4}$ gas flow ratio varied from 5 to 9 . The refractive index of the $\mathrm{SiN}_{x}$ film as a function of the $\mathrm{NH}_{3} / \mathrm{SiH}_{4}$ gas flow ratio is shown in Figure 3. It can be seen that the refractive index of $\mathrm{SiN}_{x}$ film increases with decreasing the gas flow ratio of $\mathrm{NH}_{3} / \mathrm{SiH}_{4}$, indicating that increasing Si content will increase the refractive index. There is an empirical equation to link $\mathrm{SiN}_{x}$ stoichiometry with refractive index $(n)$ : [7]

$$
n=1.22+0.61 *\left(\frac{1}{x}\right)
$$




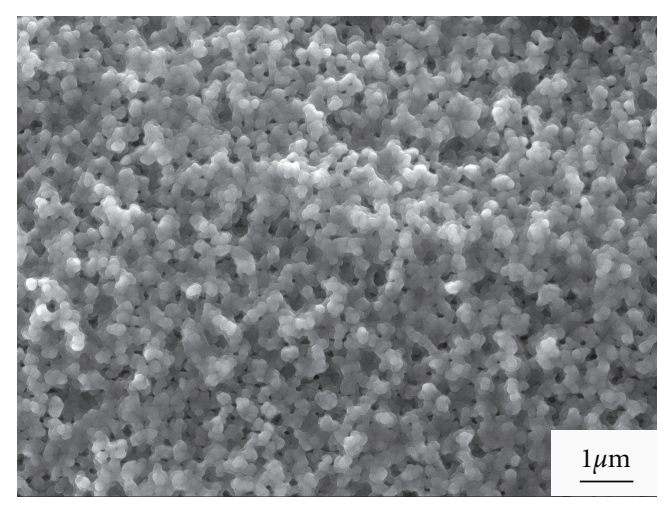

(a)

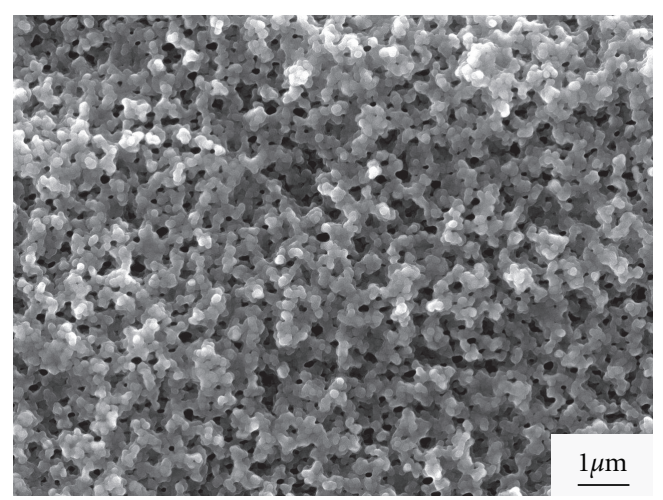

(b)

FIgURE 4: The microstructure of the as-deposited $\mathrm{SiN}_{x}$ film (a) $\mathrm{NH}_{3} / \mathrm{SiH}_{4}$ ratio $=9$ and $(\mathrm{b}) \mathrm{NH}_{3} / \mathrm{SiH}_{4}$ ratio $=5$.

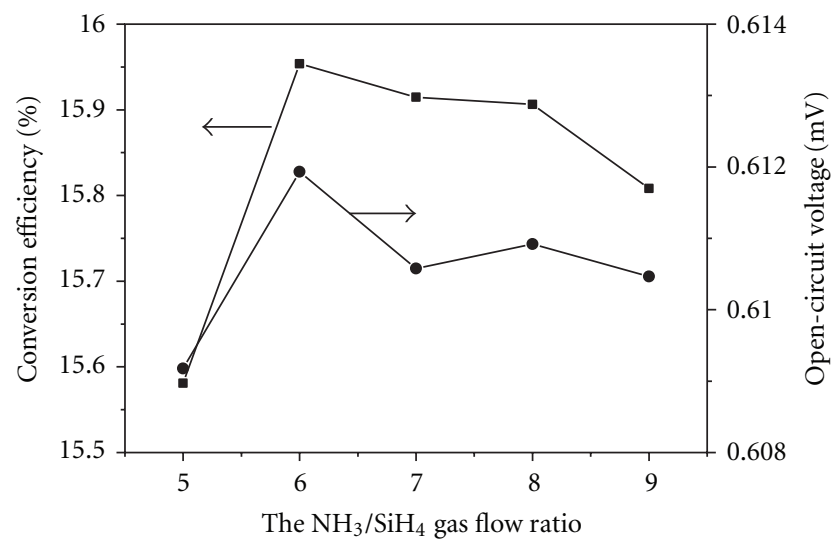

FIGURE 5: The conversion efficiency and open-circuit voltage of the black silicon solar cell varying with the $\mathrm{NH}_{3} / \mathrm{SiH}_{4}$ gas flow ratio.

where $n$ is the refractive index, and $x$ is $[\mathrm{N}] /[\mathrm{Si}]$ ratio. From Figure 3, the stoichiometries ranging from 0.59 to 0.73 for the as-deposited $\mathrm{SiN}_{x}$ film vary with the $\mathrm{NH}_{3} / \mathrm{SiH}_{4}$ gas flow ratio varying from 5 to 9 . Figure 4 shows the microstructure of the deposited $\mathrm{SiN}_{x}$ film. One can obviously see that the film becomes denser when the $\mathrm{NH}_{3} / \mathrm{SiH}_{4}$ gas flow ratio increases. As the $\mathrm{NH}_{3} / \mathrm{SiH}_{4}$ gas flow ratio increase, the $\mathrm{Si}$ content decreases, consequently, the growth rate of the film becomes slow, resulting in a much denser film.

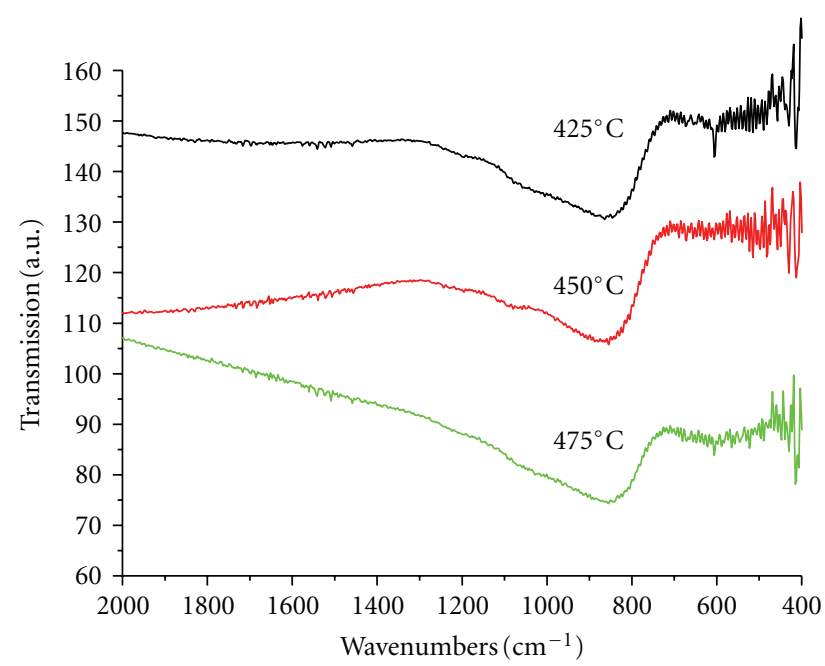

FIgURE 6: FTIR transmission spectra of $\mathrm{SiN}_{x}$ films deposited at $425^{\circ} \mathrm{C}, 450^{\circ} \mathrm{C}$, and $475^{\circ} \mathrm{C}$, respectively.

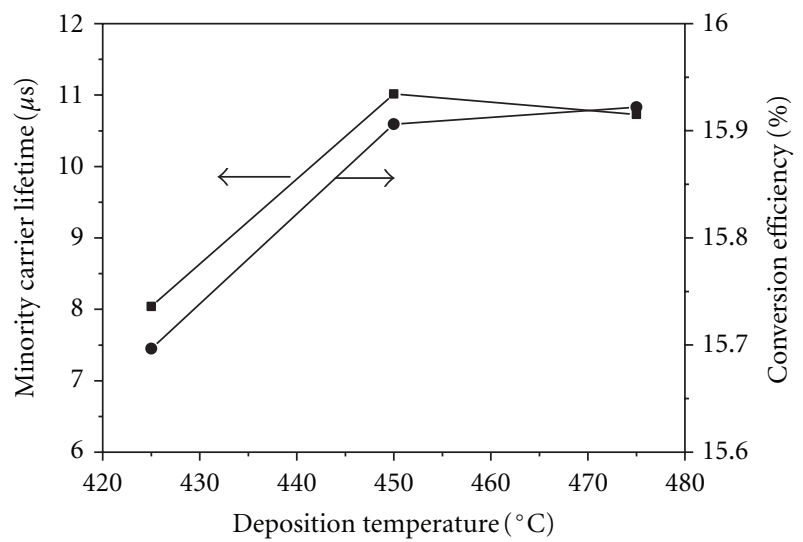

FIGURE 7: The minority carrier lifetime and conversion efficiency versus deposition temperature.

TABLE 1: The influence of deposition time on the properties of black silicon solar cells.

\begin{tabular}{ccccc}
\hline & $V_{\text {oc }}(\mathrm{V})$ & $I_{\text {sc }}(\mathrm{A})$ & $R_{s}(\mathrm{~m} \Omega)$ & $E_{\mathrm{ff}}(\%)$ \\
\hline 300 & 0.605 & 8.01 & 3.19 & 15.23 \\
500 & 0.611 & 8.25 & 3.21 & 15.91 \\
700 & 0.613 & 8.22 & 4.62 & 15.66 \\
\hline
\end{tabular}

Figure 5 shows the conversion efficiency and open-circuit voltage of the black silicon solar cell varying with the $\mathrm{NH}_{3} / \mathrm{SiH}_{4}$ gas flow ratio. The conversion efficiency and open-circuit voltage reach their highest value when the $\mathrm{NH}_{3} / \mathrm{SiH}_{4}$ gas flow ratio is 6, indicating that the $\mathrm{SiN}_{x}$ film has a good passivation effect on black silicon when the $\mathrm{NH}_{3} / \mathrm{SiH}_{4}$ gas flow ratio is 6 .

3.3. Deposition Temperature. Deposition temperature is also a crucial parameter to determine the passivation effect for black silicon in the process of PECVD $\operatorname{SiN}_{x}$ film. Keeping 


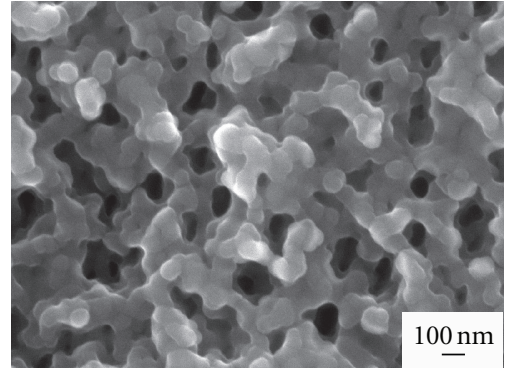

(a)

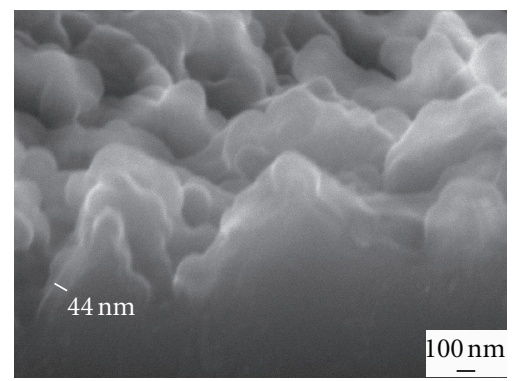

(d)

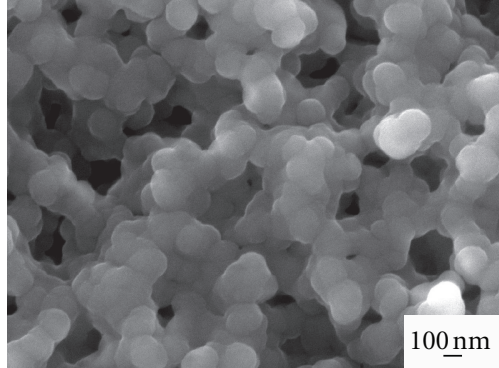

(b)

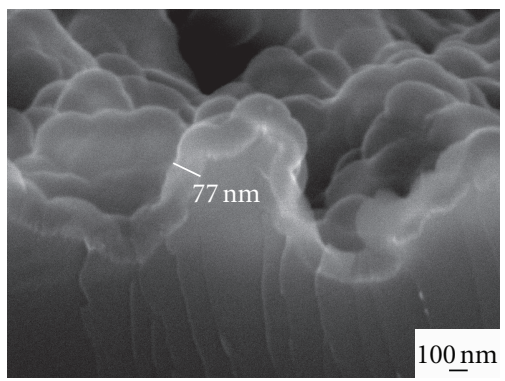

(e)

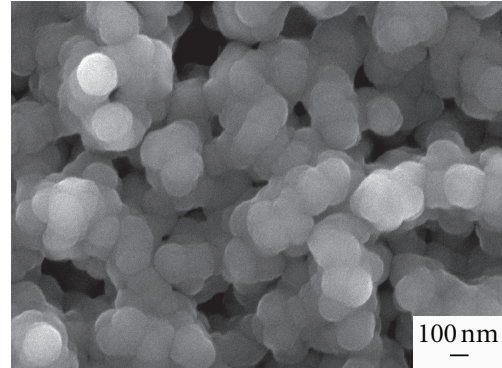

(c)

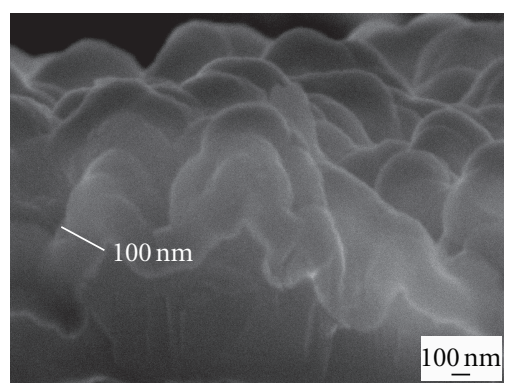

(f)

FIgURE 8: The microstructure of SiN film varying with deposition time, Top view: (a) $300 \mathrm{~s}$, (b) $500 \mathrm{~s}$, and (c) $700 \mathrm{~s}$, Side view: (d) $300 \mathrm{~s}$, (e) $500 \mathrm{~s}$, and (f) $700 \mathrm{~s}$.

the deposition time at $500 \mathrm{~s}$, deposition power at $3000 \mathrm{~W}$ and the $\mathrm{NH}_{3} / \mathrm{SiH}_{4}$ gas flow ratio at 6 , the deposition temperature is varied from $425^{\circ} \mathrm{C}$ to $475^{\circ} \mathrm{C}$. Figure 6 shows the FTIR transmission spectra of the $\operatorname{SiN}_{x}$ films grown at $425^{\circ} \mathrm{C}$, $450^{\circ} \mathrm{C}$, and $475^{\circ} \mathrm{C}$, respectively. All the spectra show a strong absorption band centered at approximately $840-890 \mathrm{~cm}^{-1}$ that can be identified with the asymmetric stretching mode of vibration of the $\mathrm{Si}-\mathrm{N}$ bond. This band shifts very slightly varying with the deposition temperature, indicating that the deposition temperature affects the chemical composition very slightly. Figure 7 shows the minority carrier lifetime and conversion efficiency of the black silicon after PECVD the $\mathrm{SiN}_{x}$ films at $425^{\circ} \mathrm{C}, 450^{\circ} \mathrm{C}$, and $475^{\circ} \mathrm{C}$, respectively. Higher deposition temperature will result in higher minority carrier lifetime and conversion efficiency. It is believed that relatively high deposition temperature facilitates hydrogen atoms diffuse into silicon substrate and consequently reduces the recombination center, contributing to an increase of conversion efficiency. Considering equipment factor, $450^{\circ} \mathrm{C}$ is preferable deposition temperature.

3.4. Deposition Time. Figure 8 shows the microstructure of the $\mathrm{SiN}_{x}$ films varying with deposition time. It can be seen that the $\operatorname{SiN}_{x}$ film becomes denser, and the thickness increases with the deposition time. Also it can be obviously seen that the $\mathrm{SiN}_{x}$ film has a good coverage on black silicon surface, and the thickness is more uniform when the deposition time is $500 \mathrm{~s}$. Table 1 shows the influence of deposition time on the properties of black silicon solar cells. The open circuit voltage gradually increases varying with deposition time from $300 \mathrm{~s}$ to $700 \mathrm{~s}$. The increase of $V_{\text {oc }}$ can be attributed to the improvement of passivation. As increasing the deposition time, more hydrogen atoms are diffused into silicon bulk to passivate defects and dislocation, leading to a decrease of recombination center. It can also be seen that the series resistance increases with increasing the deposition time. This is due to that, with increasing the thickness of $\mathrm{SiN}_{x}$ film, Ag paste is hard to fire through thick $\mathrm{SiN}_{x}$ film.

With optimizing the PECVD parameters (the $\mathrm{NH}_{3} / \mathrm{SiH}_{4}$ gas flow ratio: 6 , deposition temperature : $450^{\circ} \mathrm{C}$, and deposition time:500 s), the conversion efficiency of the black silicon solar cell can reach as high as $16.25 \%$. The currentvoltage $(I-V)$ characteristics of black silicon solar cells compared with acid-textured Si solar cell are shown in Figure 9.

\section{Conclusion}

The black silicon has been produced by plasma immersion ion implantation (PIII), and its surface appears to be porous sponge like microstructure. To passivate the black silicon, $\mathrm{SiN}_{x}$ film was deposited by inline PECVD using ammonia and silane as the reactant gas. The black silicon solar cell is high when the $\mathrm{NH}_{3} / \mathrm{SiH}_{4}$ gas flow ratio is 6 , the deposition temperature is $450^{\circ} \mathrm{C}$, and the deposition time is $500 \mathrm{~s}$. With optimizing these parameters, the conversion efficiency of black silicon solar cell reaches as high as $16.25 \%$. This work constitutes the most important step to optimize the $\mathrm{SiN}_{x}$ film, which allows us to design a desirable film for black 


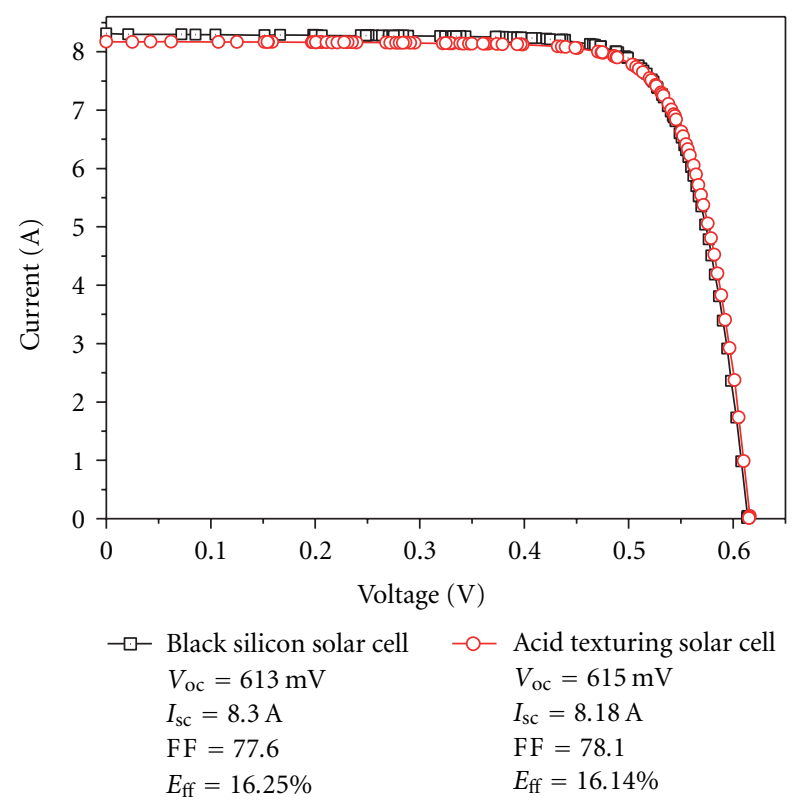

FIgURE 9: The current-voltage $(I-V)$ characteristics of black silicon solar cell compared with acid-textured Si solar cell.

silicon solar cell. Matched by adequate metallization step, the conversion efficiency of the black silicon solar cell can be further improved.

\section{Acknowledgment}

This work was supported by the National Natural Science Foundation of China (no. 61106060) and the Instrument Developing Project of the Chinese Academy Sciences (no. YZ200755).

\section{References}

[1] M. Moreno, D. Daineka, and P. R. Cabarrocas, "Plasma texturing for silicon solar cells: from pyramids to inverted pyramids-like structures," Solar Energy Materials and Solar Cells, vol. 94, no. 5, pp. 733-737, 2010.

[2] Z. Huang, N. Geyer, P. Werner, J. De Boor, and U. Gösele, "Metal-assisted chemical etching of silicon: a review," Advanced Materials, vol. 23, no. 2, pp. 285-308, 2011.

[3] C. H. Crouch, J. E. Carey, J. M. Warrender, M. J. Aziz, E. Mazur, and F. Y. Génin, "Comparison of structure and properties of femtosecond and nanosecond laser-structured silicon," Applied Physics Letters, vol. 84, no. 11, pp. 1850-1852, 2004.

[4] Y. Xia, B. Liu, J. Liu, Z. Shen, and C. Li, "A novel method to produce black silicon for solar cells," Solar Energy, vol. 85, no. 7, pp. 1574-1578, 2011.

[5] Y. Xia, B. Liu, S. Zhong, and B. Chao, "X-ray photoelectron spectroscopic studies of black silicon for solar cell," Journal of Electron Spectroscopy and Related Phenomena, vol. 184, pp. 589$592,2012$.

[6] A. El Amrani, I. Menous, L. Mahiou, R. Tadjine, A. Touati, and A. Lefgoum, "Silicon nitride film for solar cells," Renewable Energy, vol. 33, no. 10, pp. 2289-2293, 2008.

[7] S. Dauwe, Low Temperature Surface Passivation of Crystalline Silicon and Its Application to the Rear Side of Solar Cells [Ph.D. thesis], Hannover University, Hanover, Germany, 2004. 


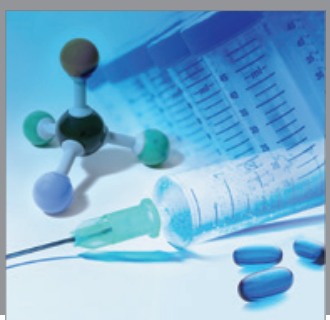

International Journal of

Medicinal Chemistry

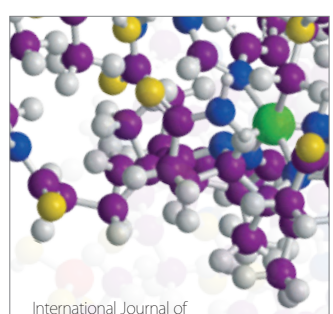

Carbohydrate Chemistry

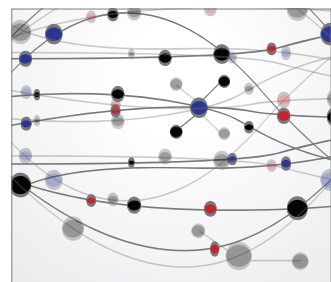

The Scientific World Journal
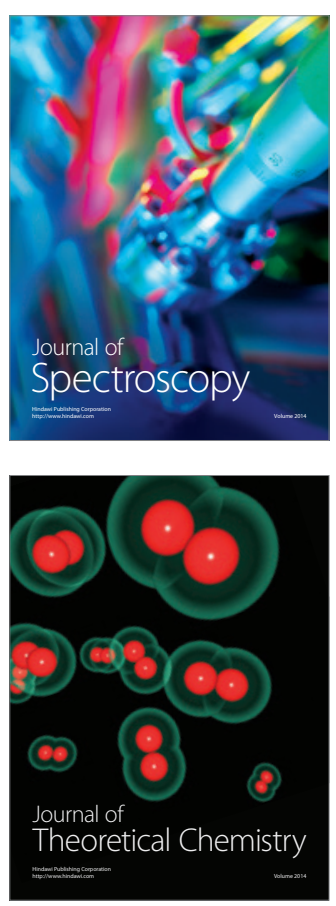
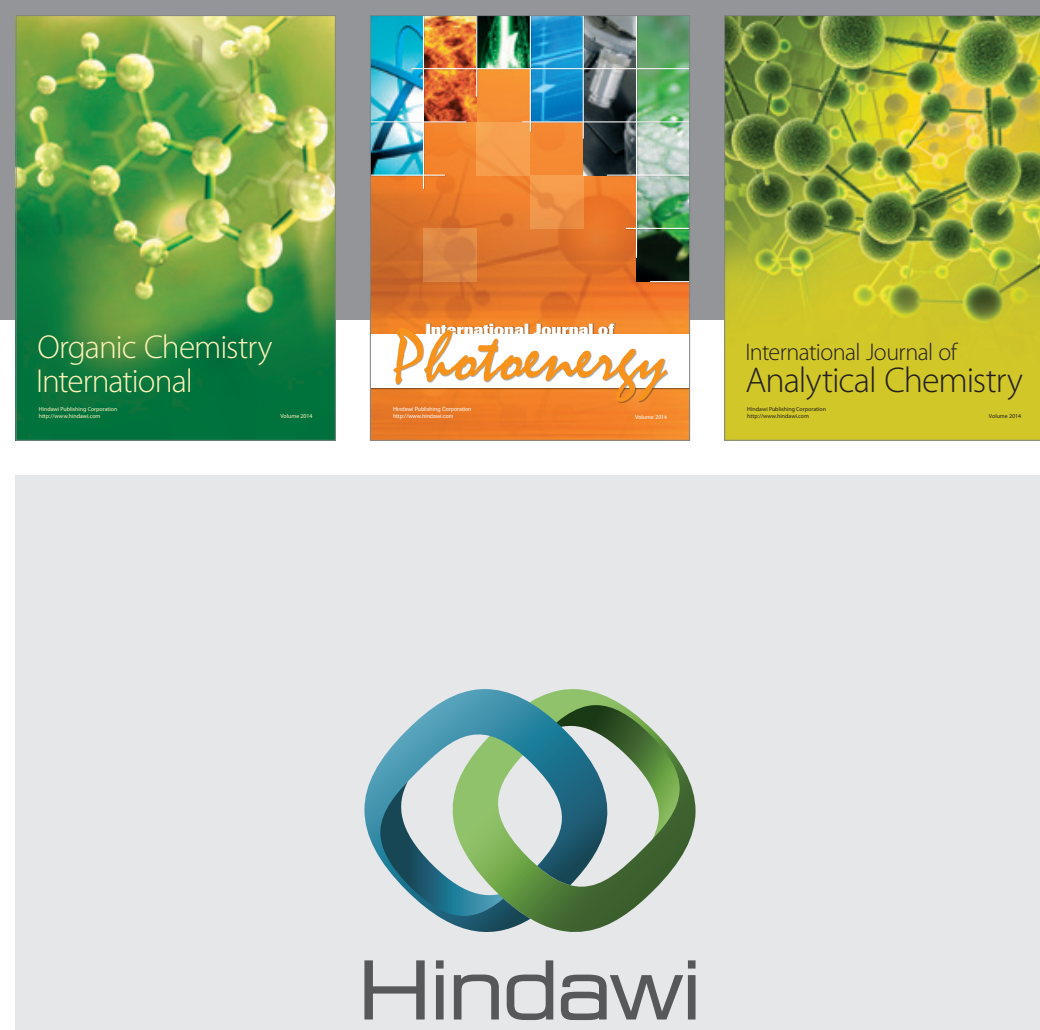

Submit your manuscripts at

http://www.hindawi.com
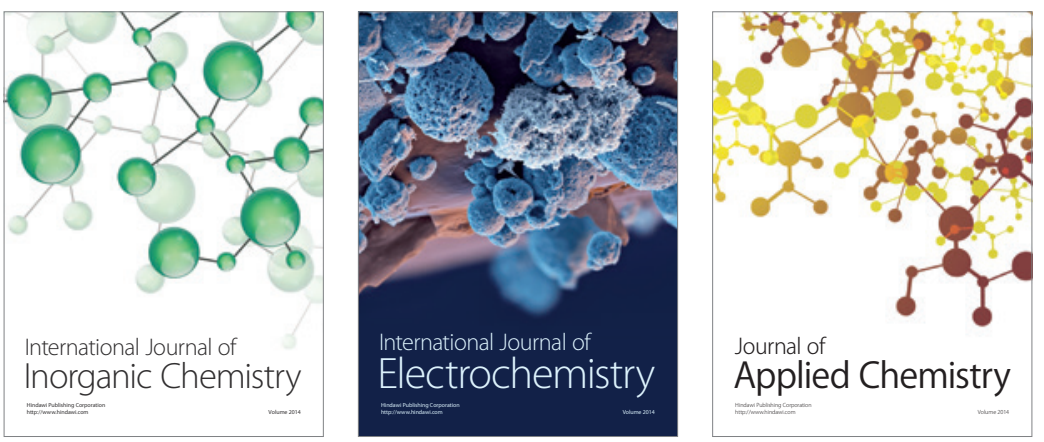

Journal of

Applied Chemistry
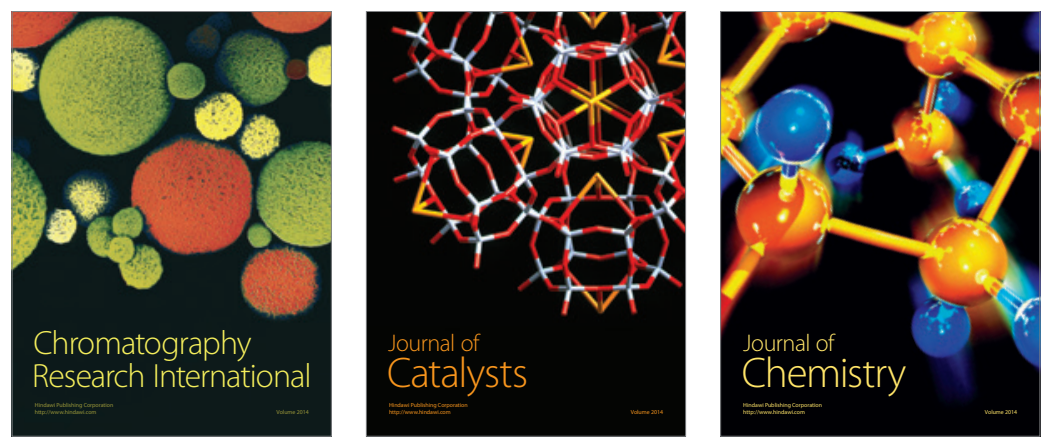
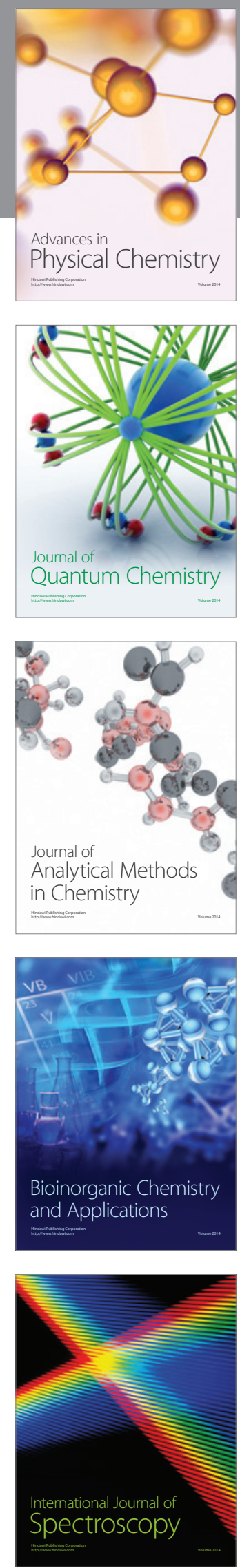